\title{
Industrial development of the countries of the Eurasian Economic Union in transition to the digital economy
}

\author{
Irina Rodionova ${ }^{1}$, Tatiana Kokuytseva, ${ }^{2, *}$ \\ ${ }^{1}$ Peoples' Friendship University of Russia (RUDN University), 117198 Miklukho-Maklaya Street, 6, \\ Russian Federation \\ ${ }^{2}$ Peoples' Friendship University of Russia (RUDN University), 117198 Miklukho-Maklaya Street, 6, \\ Russian Federation
}

\begin{abstract}
The rapid growth in high-tech production is a key development trend in the modern world industry. However, the situation in the developing countries, as well as in "transition economies" (former socialist countries) differs from the one in developed countries. The economy restructure during the transition "from plan to market" in the post-Soviet states after the collapse of the USSR did not improve the state of the industrial sector in these countries. On the contrary, some industries were lost, economic interregional and intersectoral relations were destroyed when they became sovereign countries. And their foreign trade was reoriented outside the Commonwealth of Independent States (CIS) and later the Eurasian Economic Union (EEU). The purpose of the article is to assess the degree of readiness of the EEU and the CIS countries as a whole for the digital transformation of the economy on the basis of an analysis of their innovative and industrial development. The differentiation of the EEU countries by the level of industrial development, as well as the degree of lagging behind global trends in the transition to a post-industrial economy, is revealed. The analysis of the positions of the EEU countries in international rankings showed, that these countries continue to yield to the world leaders in terms of innovation activity and economic development. Today this gap may even widen. Only three countries still correspond to the main trends of world innovative development in the post-Soviet space: Russia, Kazakhstan and Belarus. Others have difficulties in innovative and industrial development.
\end{abstract}

\section{Introduction}

In the context of the digitalization of the world economy, special attention in the scientific community is paid to the analysis of the impact of the innovative component on the socioeconomic development of states. Many researchers write about that in scientific articles, reports and reviews of international organizations, including UNIDO, UNCTAD and others [Bharadwaj et al., 2013; OECD Science .., 2017; Measuring .., 2017; Digital Planet 2017; Teece, 2018; Science and Engineering ..., 2018; UNIDO Industrial .., 2018; Global value

\footnotetext{
${ }^{1}$ Corresponding author: kokuytseva_tv@ @rudn.ru
} 
chains .., 2018; Industrial .., 2019; Watanabe et al., 2018; Watanabe et al., 2018a]. Characteristic features and prospects for the development of human potential and national innovation systems, including the ones in the countries of Central and Eastern Europe, the CIS and the EEU are characterized in scientific papers [Gierańczyk, 2010; Rodionova, 2013; Dominiak, Rachwał, 2016; Groshen et al., 2017; Kokuytseva et al., 2019]. It is emphasized that GDP of the states grows due to high-tech production and export, including the largest transnational corporations and their branches. In other words, scientists and experts show that at present the process of digital transformation of the economy offers unique opportunities for manufacturers in different countries. However, it is necessary to develop human potential and education to get closer to the leaders of the world economy,. It is necessary to implement information and communication technologies (ICT) in all spheres of the economy and human life. It is required to develop R\&D and introduce technical innovations everywhere. And it is necessary to pay attention to the development of the industrial potential of the state. In other words, the willingness of countries to adopt digital technologies stands out as a key factor in economic transformation in business, management and society as a whole. The main idea is highlighted that the governments of the leading countries invest mostly in the development of digital economy in order to increase competitiveness [Bharadwaj et al., 2013; Schwab, 2017; Competitive .., 2018; IDM World Digital .., 2019; UNIDO Industrial .., 2019; Industrial Development Report 2020]. The authors of the article are also convinced that the transition to post-industrialism and the digital economy is taking place simultaneously with the on-going process of industrialization at the global level.

It should be noted that since the beginning of the 1990s, the CIS countries have been classified as "countries that transformed the economy in the transition from a planned economy to a market economy". At the same time, some of them are included in international statistics in the group of developed countries with market economy (including Russia). However, a significant part of the CIS countries is often referred to the group of developing ones. There is a different degree of structural changes in economy and industry in this group of countries. Some of them still do not have the opportunity to introduce innovative solutions and modern technologies in their economy and industry (for various reasons: external and internal). We consider both the EEU countries (and the CIS countries due to the tendency of expanding of the EEU on the post-soviet territories.

The purpose of this article is to assess the degree of readiness of the EEU (including Armenia, Belarus, Kazakhstan, Kyrgyzstan and Russia) and the CIS countries as a whole for the digital transformation of the economy based on an analysis of the current situation in the innovative and industrial development of post-Soviet states (by comparing their positions in international ratings).

\section{Methodology}

To compare the level of industrial development of the EEU and the CIS countries as a whole, several groups of indicators were selected. Some of them characterized the general level of socio-economic development. First of all, it is an indicator of GDP at purchasing power parity per capita (GDP PPP per capita). Another group included criteria reflecting the level of industrial development of states. This is manufacturing value added (MVA) per capita, and "coefficient of industrialization". This indicator was calculated by the authors. It also characterizes the level of development of manufacturing in the CIS countries. It is calculated as the ratio of a country's share in world MVA to a share of the same country in the global population. In other words, in the more industrially developed CIS countries, this indicator is much higher than in the less developed (the range is from 0.9 in Russia to 0.01 in Kyrgyzstan; for comparison: in Switzerland - the level of industrialization is 8.2). Thus, the authors also analysed data on the population, manufacturing output, the share of countries 
in total CIS indicators, and the share of CIS countries in world industry, etc. The data of the CIS countries reflected in the Competitive Industrial Performance (CIP) Index were also analysed.

The CIP Index evaluates the position of states. This index characterizes the possibilities of technological modernization of industrial production and reflects the general influence of a country on world production and trade. The level of competitiveness in the world industry is reflected in the indicators: manufacturing value added per capita and manufactured exports per capita. Production and export indicators are estimated: the share of medium- and hightech products in the total industry, the share of manufacturing value added in countries' GDP, the share of high-tech exports in total industrial exports and the share of industrial exports in the country's total exports. The share of the country in the world manufacturing industry and in the world export of industrial products was also estimated. The ranking table for 138 countries was headed by: Germany, Japan, China, USA, Republic of Korea, Switzerland, Belgium, Netherlands, Singapore, Italy [UNIDO Industrial ..., 2020]. In other words, we indirectly took into account indicators of the level of development of high-tech production and industrial exports of the CIS countries.

The third group of indicators is the data from the rating tables of international innovation development indices. They identified the positions of the CIS countries in the world ranking table. The following indices were selected: The Global Innovation Index (GII), The Networked Readiness Index (NRI), The ICT Development Index (IDI). These ratings assess the level of implementation of innovations and information and communication technologies at the economy of different countries. An analysis was also made of the positions of the CIS countries in the "IDM World Digital Competitiveness Rankings". However, among the 63 countries analysed, only data for Russia, Kazakhstan and Ukraine were presented [IDM World Digital .., 2019].

The authors calculated the correlation coefficients between the indicators of 117 countries in the rating tables of the above indices. The correlation was very high (from 0.86 to 0.9 ). And for further comparisons and calculations only the rating table of "The ICT Development Index" was used [Measuring..Vol.1, 2017].

Next, correlations between the indicators of innovative and industrial development of 117 countries of the world (including CIS countries) were calculated. Correlation was calculated in the Excel program (the calculation standard formula was used). The determination coefficients were calculated, reflecting the tightness of the relationship between the indicators (taking into account the share of unexplained variance - the variance of the random error of the model). Charts were drawn illustrating the correlation between the indicators.

To identify the level of readiness of the CIS countries for the digital transformation of the economy, all the data on a level of innovative and industrial development (selected for analysis) were analysed.

\section{Study Results and Discussion}

Initially, it is worth recalling the growth in world industrial production. And remember the leaders in manufacturing value added (MVA).. So, as before, over 55\% of the world production of manufacturing products is produced in industrialized countries [Competitive .., 2018; UNIDO Industrial .., 2018]. Among the first 15 countries (which account for more than $80 \%$ of world industrial production) is Russia. According to UNIDO experts, the leader was China (25\% of the global value of manufacturing industries, 2018), the USA (15\%), Japan (about 10\%), Germany, India, the Republic of Korea, Italy, Brazil, Indonesia. [Industrial Development .., 2020; UNIDO Industrial Statistics .., 2020]. Russia takes only the 10th position (1.7\%). MVA (billion \$, 2018) of other CIS countries is even lower. The indicator of MVA per capita for all CIS countries are much less in comparison with the 
leading countries of the world industry. So, in Japan this indicator is 10366 US\$, 2018, in Germany - 10268, in the USA - 6200, and even in China - 2383 at constant 2010 prices in US\$, 2018. And, for example, in Russia this indicator is 1585 US\$, in Kazakhstan - 1110 US\$ [UNIDO Industrial Statistics .., 2020]. At the same time, the CIS countries are very significantly different from each other both in the number of inhabitants and in the level of socio-economic and, including industrial development (Table 1, Table 2). The sources of statistic data for the Table 1 and Table 2 are [The World Facebook, 2020; UNIDO. Industrial Statistics.., 2020].

Table 1. Selected indicators of economic development of the CIS countries, 2018.

\begin{tabular}{c|c|c|c|c|c}
\hline & $\begin{array}{c}\text { GDP (PPP) per } \\
\text { capita (US\$ ) }\end{array}$ & $\begin{array}{c}\text { Population } \\
(\mathbf{m l n})\end{array}$ & $\begin{array}{c}\text { Share in the } \\
\text { CIS }(\boldsymbol{\%})\end{array}$ & $\begin{array}{c}\text { GDP (PPP) } \\
(\text { bln US\$) }\end{array}$ & $\begin{array}{c}\text { Share in the } \\
\text { CIS (\%) }\end{array}$ \\
\hline Russia & 27900 & 142,12 & 50,6 & 4016,0 & 71,1 \\
\hline Kazakhstan & 26300 & 18,74 & 6,7 & 478,6 & 8,5 \\
\hline Belarus & 18900 & 9,53 & 3,4 & 179,4 & 3,2 \\
\hline Turkmenistan & 18200 & 5,41 & 1,9 & 103,7 & 1,8 \\
\hline Azerbaijan & 17500 & 10,05 & 3,6 & 172,2 & 3,0 \\
\hline Armenia & 9500 & 3,04 & 1,1 & 28,34 & 0,5 \\
\hline Ukraine & 8800 & 43,95 & 15,7 & 369,6 & 6,5 \\
\hline Uzbekistan & 6900 & 30,02 & 10,7 & 223,0 & 3,9 \\
\hline Moldova & 6700 & 3,44 & 1,2 & 23,72 & 0,4 \\
\hline Kyrgyzstan & 3700 & 58,5 & 2,1 & 23,15 & 0,4 \\
\hline Tajikistan & 3200 & 8,60 & 3,1 & 28,43 & 0,5 \\
\hline
\end{tabular}

Table 2. MVA and CIP rank of the CIS countries, 2018.

\begin{tabular}{c|c|c|c|c}
\hline & MVA (bln US\$) & $\begin{array}{c}\text { Share in the } \\
\text { CIS (\%) }\end{array}$ & $\begin{array}{c}\text { MVA per } \\
\text { capita (US\$) }\end{array}$ & CIP rank, 2018 \\
\hline Russia & 228,1 & 72,9 & 1585 & 31 \\
\hline Kazakhstan & 20,4 & 6,5 & 1110 & 66 \\
\hline Belarus & 14,8 & 4,7 & 1563 & 46 \\
\hline Turkmenistan & 17,0 & 5,4 & 2904 & - \\
\hline Azerbaijan & 3,1 & 1,0 & 316 & 115 \\
\hline Armenia & 1,3 & 0,4 & 459 & 99 \\
\hline Ukraine & 14,0 & 4,5 & 319 & 67 \\
\hline Uzbekistan & 11,3 & 3,6 & 350 & - \\
\hline Moldova & 0,9 & 0,3 & 225 & 106 \\
\hline Kyrgyzstan & 0,9 & 0,3 & 146 & 118 \\
\hline Tajikistan & 1,1 & 0,4 & 121 & 131 \\
\hline
\end{tabular}

Comparing the share of states in the total data for the CIS, we see that Russia has the largest share. This country is the undisputed leader in the post-Soviet space.

A high positive correlation (0.7-0.8) was found between the innovation development rating data (according to the IDI Index) and the three indicators we selected for analysis: MVA per capita, GDP (PPP) per capita and "coefficient of industrialization". A low correlation was obtained between the data of the CIP Index rating table for countries and the rating table data for IDI, reflecting the level of their innovative development. However, the correlation of countries in the rating table CIP Index and "coefficient of industrialization", MVA per capita, GDP (PPP) per capita was also high (0.7-0.8). But, as the analysis showed, each of the rating tables for all indicators needs to be analysed more deeply.

In the rating "The Global Innovation Index, 2018" (GII), the situation in 126 countries is assessed by indicators characterizing the level of ICT development and the effectiveness of innovative activity. In the rating table, the highest position from the CIS countries is Ukraine 
(43rd). Russia has the 46th position between Vietnam and Chile, Kazakhstan - 74th (between the Philippines and Mauritius with Morocco), Belarus - 86th. And Tajikistan is generally located in 101st place (between Senegal and Guatemala). The leaders of the ranking: Switzerland, the Netherlands, Sweden, the UK and Singapore [The Global Innovation ..., 2018]. Below are the data on the positions of the CIS countries in other rating tables (table. 3). The sources of statistic data for the Table 3 are [Measuring .., 2017; The Global Innovation.., 2018; The Global Information .., 2016; Human Development.., 2019].

Table 3. Leading countries of innovative development and the place of the CIS countries.

\begin{tabular}{|c|c|c|c|c|c|c|c|}
\hline \multicolumn{2}{|c|}{$\begin{array}{c}\text { The Global } \\
\text { Innovation Index } \\
\text { (GII), } 2018\end{array}$} & \multicolumn{2}{|c|}{$\begin{array}{c}\text { The Networked } \\
\text { Readiness Index } \\
\text { (NRI), } 2016\end{array}$} & \multicolumn{2}{|c|}{$\begin{array}{l}\text { The ICT Development } \\
\text { Index, } 2017\end{array}$} & \multicolumn{2}{|c|}{$\begin{array}{c}\text { Human } \\
\text { Development } \\
\text { Indicators (HDI), } \\
2018\end{array}$} \\
\hline 1 & Switzerland & 1 & Singapore & 1 & Island & 1 & Norway \\
\hline 2 & Netherlands & 2 & Finland & 2 & $\begin{array}{l}\text { Republic of } \\
\text { Korea }\end{array}$ & 2 & Switzerland \\
\hline 3 & Sweden & 3 & Sweden & 3 & Switzerland & 3 & Ireland \\
\hline 4 & UK & 4 & Netherlands & 4 & Denmark & 4 & Germany \\
\hline 5 & Singapore & 5 & USA & 5 & UK & 5 & Hong Kong \\
\hline 43 & Ukraine & 39 & Kazakhstan & 32 & Belarus & 49 & Russia \\
\hline 46 & Russia & 41 & Russia & 45 & Russia & 50 & Belarus \\
\hline 48 & Moldova & 53 & Azerbaijan & 52 & Kazakhstan & 51 & Kazakhstan \\
\hline 68 & Armenia & 56 & Armenia & 59 & Moldova & 81 & Armenia \\
\hline 74 & Kazakhstan & 64 & Ukraine & 65 & Azerbaijan & 87 & Azerbaijan \\
\hline 82 & Azerbaijan & 71 & Moldova & 75 & Armenia & 88 & Ukraine \\
\hline 86 & Belarus & 95 & Kyrgyzstan & 79 & Ukraine & 107 & Moldova \\
\hline 94 & Kyrgyzstan & 104 & Tajikistan & 95 & Uzbekistan & 108 & Turkmenistan \\
\hline 101 & Tajikistan & - & Belarus & 109 & Kyrgyzstan & 109 & Uzbekistan \\
\hline- & Uzbekistan & - & Uzbekistan & - & Turkmenistan & 122 & Kyrgyzstan \\
\hline- & Turkmenistan & - & Turkmenistan & - & Tajikistan & 125 & Tajikistan \\
\hline
\end{tabular}

Analysis of the rating tables of several indices, reflecting the degree of readiness of the countries for the digital transformation of the economy, showed that Russia is not always a leader among the CIS countries Ukraine, or Kazakhstan, or Belarus can be ahead of Russia... In our opinion, this can be explained by the significant differentiation of Russian regions by the level of ICT development on their territories (Moscow and St. Petersburg and several other large cities are leaders. But it is not all of Russia). It is also worth noting that certain indicators of innovative development (the number of telephones, mobile cellular, fixed broadband per 100 inhabitants, the share of households with computers and Internet access, the number of Internet users among the population) in Russia, Kazakhstan and Belarus is higher than the CIS average, and even higher than the global average [Measuring the Information ... Vo. 2. ICT country profiles, 2017]. But these indicators are much lower than those in highly developed countries, which they want to be equal.

Thus, in Digital Competitiveness Rankings (IDM World Digital Competitiveness Rankings, 2019) among 63 analysed countries, only 3 CIS countries are represented. Kazakhstan is on the 35 th position, Russia - the 38th, Ukraine - the 60th out of 63 . And the leaders are: the USA, Singapore, Sweden, Denmark, Switzerland [IDM World ..., 2019].

It can be concluded that rather low positions of Russia and other CIS countries in the ratings, which are analysed, indicate the presence of serious problems in the development of national innovative systems and characterize rather low efficiency of innovative development strategies. Tajikistan and Kyrgyzstan, sometimes Moldova and Armenia (along with many 
least developed African and Asian countries) are often closer to the end of the rating table. Moreover, there is often no data on Turkmenistan and Uzbekistan in the ratings that does not indicate their high level of development, but rather closed economies.

We can only agree or disagree with the positions of countries in the rating tables, since we know the general situation in the CIS countries. Perhaps the situation does not so deplorable. For example, the fact that the position of Belarus (86) in the ranking on the "The Global Innovation Index" for 2018 is lower than the positions of Ukraine and Moldova looks rather strange. The rank of Kazakhstan (74th) is much lower than that one of Ukraine, Russia, Moldova, Georgia and Armenia (Table 2). Nevertheless, we analyse the innovation development indices presented by well-known international organizations.

Experts emphasize that a distinctive feature of the current situation in the world is that many technologies, which entail economic transformation, are available almost everywhere. Nevertheless, the gap in the ability of countries to use new opportunities is very large, which is explained in terms of inequality and human development [Human Development .., 2018].

On the whole, a comparison of the positions of the leading countries of the world economy and the CIS countries in the rating tables of innovative and industrial development showed that they mainly occupy positions in the middle of the list, and some of them are even closer to the end of the ratings.

Currently, legislative documents are being developed in the Russian Federation and other CIS countries that approve the movement of our countries in the direction of innovative development. But too little space in the Strategies of innovative development is given to fundamental science. Sadly, the quality of education at all levels in the CIS countries continues to decline.

To implement all the decisions of these strategies and concepts, a rather strict state policy and a significantly more significant amount of funding for the scientific and innovative sphere are required.

\section{Conclusion}

Currently, we are talking about a new world development paradigm - Industry 4.0. The world leaders will definitely control the global economy in the 21 st century due to the latest information technologies that directly affect production, consumption and living standards of the population. The fourth industrial revolution is able to unite the world production of various types of products and the global information network into a single Internet of things.

The article attempts to identify some correlation between the level of innovative and industrial development through a comparison of several economic indicators. Without a doubt, the gap in the readiness of the states of a different type and level of socio-economic development for the digital transformation of the economy (including its industrial sector) in the world is only widening. This fact is especially noticeable in the analysis of innovation development rating tables. Highly developed countries with a high level of readiness to develop a digital economy always occupy the top positions. The analysis and comparison of the criteria for innovative and industrial development allow us to fix several groups of countries. On the one hand, these are small, highly developed countries of Western Europe. Further, the ratings usually are highly developed countries of other regions of the world (USA, Canada, Japan, Australia, and the main group of EU countries). Also may be show a group of states which develop their economies due to the achievements of scientific and technical progress (the Republic of Korea, China, India, Asian NIS, and the Persian Gulf states). By many indicators of industry development, these countries have already caught up, or even surpass developed European countries. At the opposite side (at the end of the rating tables) there is a large group of African and Asian countries that are still very far from the digitalization stage of the economy (these are the least developed countries - LDC). 
In the middle of the ratings of industrial development, there is a group of former socialist countries - former republics of the USSR (the EEU and CIS countries). Moreover, as the analysis of the positions of the CIS countries (especially Asian) in international rankings showed, they continue to be significantly inferior to the leading world leaders in terms of innovation activity and economic development.

As the past three decades have shown, the restructuring of the economy during the transition "from plan to market" in the post-Soviet states after the collapse of the USSR did not improve their industry. On the contrary, economic interstate and inter-industry ties between the republics were destroyed. They became sovereign in the early 1990s and reoriented their foreign trade to states outside the CIS and later the EEU. At the same time, it is impossible to judge the current level of industry development only by positions of the EEU and the CIS countries as a whole in various rating tables. A multicomponent characteristic is needed to show different aspects of the level of innovative development and industrialization of the EEU countries. A more significant amount of funding as well as strong state policy are needed to implement all the decisions of the Strategies and Concepts of economic development of the EEU countries for the scientific and innovative sphere development.

The study was supported by the Russian Federal Property Fund in the framework of research project No. 19-010-00609 "Development of forecast scenarios EAEU's socio-economic development for the medium and long term perspective based on the construction of simulation models of assessment EAEU integration potential and analysis of economic and geopolitical factors and challenges with an assessment of their impact on the Union. "

\section{References}

1. A. Bharadwaj, O. El Sawy, P. Pavlou, \& N. Venkatraman, MIS Quarterly, 37(2), 471482 (2013)

2. Competitive Industrial Performance Report, Biennial CIP report, edition 2018 (UNIDO, Vienna, 2019). URL: https://www.unido.org/sites/default/files/files/2019-05/CIP.pdf

3. Digital Planet, How Competitiveness and Trust in Digital Economies Vary Across the World. Bhaskar Chakravorti and Ravi Shankar Chaturvedi. The Fletcher School, Tufts University (2017).

URL: https://sites.tufts.edu/digitalplanet/files/2017/05/Digital_Planet_2017_FINAL.pdf

4. Global value chains and industrial development, Lessons from China, South-East and South Asia, (UNIDO. 2018). URL: https://www.unido.org/sites/default/files/files/2018-06/EBOOK_GVC.pdf

5. E.L. Groshen, B.C. Moyer, A.M. Aizcorbe, R. Bradley, D.M. Friedman, J. Econ. Perspect, 31 (2), 187-210 (2017)

6. Human Development Report, Beyond income, beyond averages, beyond today: Inequalities in human development in the 21 st century (USA, Oxford University Press, 2019). URL: http://hdr.undp.org/sites/default/files/hdr_2019 overview-russian.pdf

7. IDM World Digital Competitiveness Rankings, World Competitiveness Center (2019). URL: https://www.imd.org/wcc/world-competitiveness-center-rankings/world-digitalcompetitiveness-rankings-2019/

8. Industrial Development Report, Industrializing in the digital age (UNIDO, 2019) https://www.unido.org/sites/default/files/files/2019-11/UNIDO_IDR2020English_overview.pdf

9. T.V. Kokuytseva, I.A. Rodionova, V. Damnjanovic, 51-59 (Contributions to Economics. Springer Nature Switzerland, 2019) 
10. Measuring the Information Society Report, The ICT Development Index (IDI) (2017). URL: https://www.itu.int/en/ITU-

D/Statistics/Documents/publications/misr2017/MISR2017_Volume1.pdf

11. Measuring the Information Society Report, ICT country profiles (2017). URL: https://www.itu.int/en/ITU-

D/Statistics/Documents/publications/misr2017/MISR2017_Volume2.pdf

12. OECD Science, Technology and Industry Scoreboard (2017). URL: http://www.oecd.org/sti/oecd-science-technology-and-industry-scoreboard20725345.htm

13. I. Rodionova, Quaestiones Geographicae, 32(2), 15-24 (2013). URL:http://www.degruyter.com/view/j/quageo.2013.32.issue-2/quageo-20130010/quageo-2013-0010.xml?format

14. Science and Engineering Indicators (VA: National Science Foundation, USA, 2018). URL: http://nsf.gov

15. D. Teece, Research Policy, 47(8), 1367-1387 (2018).

16. The Global Competitiveness Report, World Economic Forum. Geneva, Switzerland 2018 (2018).

URL: http://www3.weforum.org/docs/GCR2018/05FullReport/TheGlobalCompetitivenessR eport2018.pdf

17. The Global Information Technology Report, World Economic Forum (2016). URL: https://www.wsj.com/public/resources/documents/GITR2016.pdf

18. The Global Innovation Index, Energizing the World with Innovation. INSEAD (The Business School for the World) and the World Intellectual Property Organization (WIPO, 2018). URL: https://www.wipo.int/edocs/pubdocs/en/wipo_pub_gii_2018.pdf

19. The World Facebook. Central Intelligence Agency. URL: https://www.cia.gov/library/publications/the-world-factbook/

20. UNIDO Industrial Development Report, Demand for Manufacturing: Driving Inclusive and Sustainable Industrial Development. Overview (Vienna. UNIDO, 2018)

21. UNIDO. Industrial Statistics Database. INDSTAT4 (2020). URL: https://stat.unido.org/app/country/Basic.htm?Country=372\&Group=null

22. C. Watanabe, Y. Tou, P. Neittaanmäki, Technology in Society, 55, 9-23 (2018)

23. C. Watanabe, K. Naveed, Y. Tou, P. Neittaanmäki, Technological Forecasting and Social Change, 137, 226-240 (2018a). 